\title{
19
}

\section{The National Social Security Fund}

\section{Tim Murton}

The establishment of the National Social Security Fund (NSSF) is a significant step for China in addressing the magnitude of its current pension problem, and in assisting the Chinese Government to service its pension liabilities. Moreover, it is an important indication of China's desire to encourage the development of institutional investors. Despite this, the NSSF is still shrouded in some mystery. This chapter attempts to provide an insight into the management, funding and operation of the NSSF. The NSSF's role in developing China's fledgling funds management industry will also be considered.

\section{THE NATIONAL SOCIAL SECURITY FUND}

The NSSF, which was set up in the second half of 2000 , was only widely publicised by the Chinese Government in 2001. It was set up to act as a stable, medium to long-term reserve fund, with its main objective to ensure the future sustainability of China's social security system, particularly in relation to the provision of pensions. It is in this context that the Chinese Government hopes that the NSSF will remain untouched for at least 20 years, in order to enable it to accumulate sufficient funds to cover any future shortfalls in social security funding. Many commentators, such as Leckie (2002) and DiBiasio (2002b:28), have noted that the NSSF's role is that of a 'fund of last resort'. As such, the NSSF is expected to reduce the need for budgetary top-ups of the future pension shortfalls of Provincial Governments, particularly as the impact of China's ageing population becomes more severe. Such a view assumes 
that the NSSF is a large fund pool, which will be paid out as required. This chapter assumes that the NSSF is, in fact, a large fund pool that will be used to cover future pension shortfalls as a last resort.

While there is, generally speaking, broad consensus with regard to the role of the National Social Security Fund, other commentators, such as Ogborn, ${ }^{1}$ suggest that the NSSF consists of a multitude of individual accounts. This view is incorrect. The costs associated with managing a range of individual accounts, and keeping them separate from one another to ensure their integrity, would make it too costly for most fund managers to want to be actively involved in the management of such funds. In this way, a structure based around a set of individual accounts would not be attractive to most fund managers, and would defeat the purpose of the Chinese Government in using the NSSF to encourage institutional investors in that country.

In its role as a large fund pool, the NSSF is considered by the Chinese Government to be a kind of Trust Fund.

\section{Management and structure of the National Social Security Fund}

In the context of funds management, the NSSF Council, which reports directly to the State Council, acts as a Board of Trustees. It is the main decision making body, and is made up of representatives from Government, business and academia. Among its members, all of which are appointed by the State Council, are Xiang Huaicheng, the former Minister for Finance and who was recently appointed President of the Council, Gao Xiqing, former Vice Chairman of the China Securities Regulatory Commission and who was recently appointed as the Vice President of the Council, and Liu Yongfu, Vice-Minister for Labour and Social Security, and Feng Jianshen, mentioned below, who are Councillors.

Although the Chinese Government views the NSSF as a Trust Fund, it is doubtful whether this is justified at this time. Generally speaking, Trust Funds are clearly defined and bound by relevant legislation and must specify details regarding sources of funding, how the funds will be invested, and how payments will be made. Information regarding the operation of the National Social Security Fund is available regarding the first two criteria. However, there is a general lack of information available for the last criterion. To date, there has been no clear indication from the Chinese Government of how payments from the NSSF will be made available to provincial governments. 
With regard to its function as a Board of Trustees, the Council of the Chinese National Social Security Fund has appointed a number of custodians and funds management companies to manage part of the NSSF's assets. Of particular relevance to this chapter, the Council has appointed two custodians to oversee the activities of the six funds management companies, which act as investment managers. Those organisations are the Bank of Communications (Jiaotong Yinhang) and the Bank of China (Zhongguo Yinhang). The six funds management companies selected by the Council were Boshi Fund Management, Penghua Fund Management, Nanfang Fund Management, Changsheng Fund Management, Jiashi Fund Management and Huaxia Fund Management.

Under the Council of the NSSF, there is a Secretariat, which is responsible for the day-to-day administration of the Council. It consists of the Administrative Affairs Section, the Finance and Accounting Section, the Investment Management Section, the Stock Management Section, and the Legal and Supervision Section.

In addition to the Secretariat, there are a number of committees directly under the control of the Council of the NSSF. Those committees are the Investment Committee, the Risk Management Committee, and the Specialist Evaluation Committee.

The Chinese Ministries of Finance, and Labour and Social Security, also have a role in the supervision of the NSSF, though that role is still unclear.

The Council of the National Social Security Fund has sought the assistance of consultants to provide advice and training in the areas of asset allocation and risk management. With regard to the role of those consultants, it should be noted that, at present, they do not perform the role of a consultant in the traditional funds management context. The NSSF's consultants do not provide advice directly to the Council of the NSSF regarding the allocation of the fund's assets and which funds management company should be employed to invest the funds, as is their traditional role. At the moment, the NSSF's consultants are largely involved with training staff in funds management principles and techniques, and in a wide range of risk management procedures. The role of consultants in the future remains unclear, though it is possible that they will be able to provide direct advice to the Council of the NSSF. In this way, there is scope for foreign fund managers that specialise in this function to play an active role in developing China's fledgling funds management industry, and in reforming China's social security system. While there are a number of consultants working with the NSSF at present, the three major ones are Principal Insurance, Northern Trust Investor Services and Caisse des Dépots et Placements du Quebec. ${ }^{2}$ 
It is clear that the fund managers report both to the custodians and to the Council (Figure 19.1). The custodians hold title to the assets of the fund managers, and may report to the Council, represented in Figure 19.1 by a dotted arrow. Consultants work with the Council of the NSSF and report to it, as do the Secretariat and its Committees. The diagram makes it clear that the Council of the NSSF itself reports to the State Council. The ministries of Finance and Labour and Social Security only have a supervisory function.

\section{FUNDING OF THE NATIONAL SOCIAL SECURITY FUND}

Although the NSSF, in theory, receives funding from the welfare lottery and the proceeds from the sell off of State shares, its major source of funding is the budgetary finances of the Central Government. The Ministry of Finance provides an undefined amount of money each year, in the form of a special block transfer, to top up the National Social Security Fund, thus ensuring that it 'maintains and increases its value'. The amount of funds provided by the Ministry of Finance is variable, and

Figure 19.1 Reporting structure of the National Social Security Fund

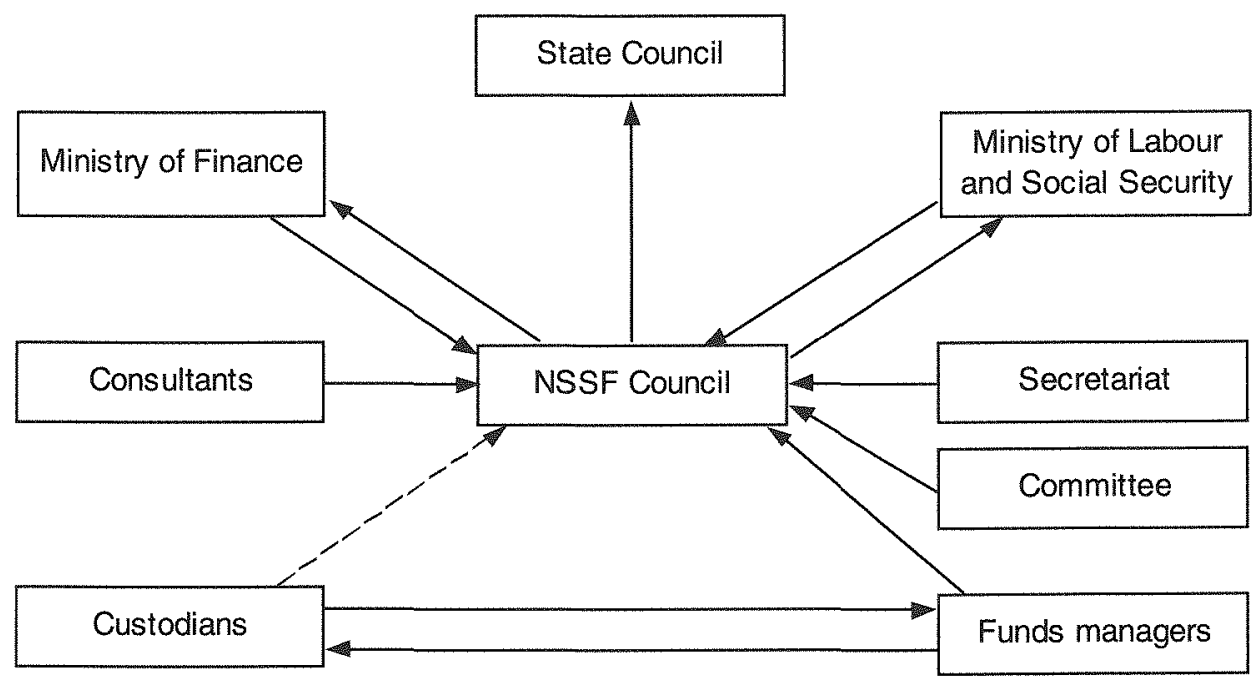


depends largely upon the financial situation regarding the revenues and expenditures of the Central Government's finances towards the end of each financial year.

Although the NSSF currently receives funds from the sell off of State shares, this amount of funding is very limited. The sell off of such shares was halted indefinitely because individual investors in China's stockmarkets feared a flood of shares, which caused them to drop sharply in value. However, State shares still account for some of the funding of the NSSF. An amount equivalent to 10 per cent of the Initial Public Offering or rights issues on those state-owned enterprises that list on overseas stockmarkets must be paid to the NSSF. There has also been speculation that the Chinese Government is considering another sell off of State shares. DiBiasio (2002b:28) comments that it is possible that the Chinese Government will transfer direct ownership of blocks of State shares to the NSSF, which would then sell them off. In this way, the NSSF could bundle them together and sell them off to strategic investors in much the same way as the Tracker Fund in Hong Kong when the Hong Kong government intervened in the stock market after the East Asian financial crisis.

The return on investment is also an important part of the NSSF's funding. Last year, the NSSF achieved a rate of return of 2.75 per cent, up from 2.25 per cent in 2001 (China Labour Net 2003). Although not clearly stated, these are not real rates of return. The rates of return to date indicate that the NSSF is beating price inflation but not salary inflation. At the end of 2002, the funds of the NSSF were invested as follows:

- bank deposits: RMB 93.9 billion, comprising 75.6 per cent of the fund's value;

- bonds: RMB 27.4 billion, comprising 22.1 per cent of the fund's value;

- other equities, including corporate bonds and stocks: RMB 1.05 billion, comprising 1.5 per cent of the fund's value (Xiao 2003).

The value of the National Social Security Fund at the end of 2002 was approximately RMB 124.2 billion (A\$24.84 billion), of which the Ministry of Finance provided RMB 59.526 billion ( $A 11.9$ billion) in the 2001 fiscal year, and RMB 41.6 billion ( $A \$ 8.32$ billion) in 2002 (China Labour Net 2003).

\section{RECENT DEVELOPMENTS}

Following the establishment of the National Social Security Fund in late 2000, it took a long time for the Council to formulate a plan on how the fund would operate. In an important development, Feng Jianshen, one of the councillors of the NSSF, commented at the $35^{\text {th }}$ Asian Development Bank Meeting, held in Shanghai in May 
2002, that the operation of the NSSF had been settled upon. The Chinese Government decided that social security funds in the NSSF would be invested in a more diverse way. From his comments, it is understood that 50 per cent of the funds will remain in Government bonds and bank deposits, which currently remain the only form of approved investments for social security funds, 10 per cent will be invested in enterprise bonds, and the remaining 40 per cent will be able to be invested in stocks, equities and securities ( $X u$ and Chen 2002).

The Chinese Government expects that such a break up of investment streams will provide a higher return for the investment of assets in the NSSF. While this 40 per cent is a positive move, and will help to develop China's fledgling securities and capital markets, it is not clear whether those funds will be able to be invested in overseas markets, especially since the Chinese currency is not convertible. It is also clear from the funding split that the Government appears to favour the use of bonds as an investment mechanism to raise more social security funds, although it could also be said that the Chinese Government is diversifying the scope of the NSSF and is trying to contain risk in the most effective way possible.

Figure 19.2 Funding of the National Social Security Fund

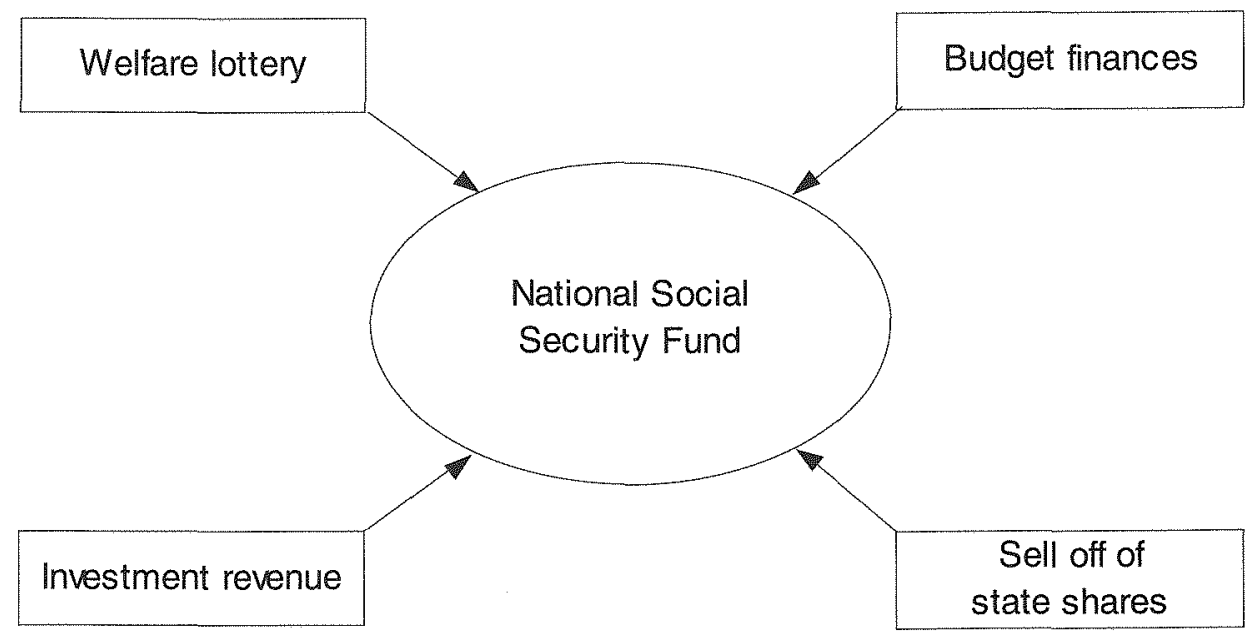


In the current environment, the NSSF's reliance on bonds as the major form of investment appears to be a prudent move, especially since bonds have generally been quite stable in their performance in recent times. However, with the current upturn in stockmarkets all over the world, apart from China, it is increasingly likely that the returns on investments of NSSF assets will become more important over time. Moreover, it is clear that, by diversifying the NSSF's investments in this way, the Chinese Government is looking to the future, and is genuinely making an effort to try to maintain and increase the fund's value.

In July 2001, the NSSF was given permission to invest RMB 300 million ( $A \$ 60$ million) in Sinopec shares on the A-based Share market. The current value of those shares is approximately RMB 900 million ( $\$ \$ 180$ million). Although this move was viewed as a pilot program, the Chinese Government also wanted the NSSF to become a strategic investor in Sinopec. While highlighting the emphasis that the Chinese Government places on developing institutional investors in China's emerging stockmarkets, this investment represented only a small portion of the value of China's stockmarkets, and reflects the insubstantial involvement of institutional investors in those markets at present. At 31 December 2002, the value of all shares in China was valued at approximately US $\$ 500$ billion, while those shares floated on the stock market represent a total value of approximately US $\$ 150$ billion (Leckie 2001). Institutional investment in China's stockmarkets comprises 10 per cent of the market, with fund investments making up 1.7 per cent of the market (Leckie 2001).

The move to encourage institutional investors is widely regarded as a positive one, although it is acknowledged that it will take some time before institutional investors become a dominant force in the stock market, as they have done in many developed economies, such as those of the United States of America and Australia. The involvement of the NSSF in China's stockmarkets, coupled with the recently approved Qualified Foreign Institutional Investor (QFII) scheme, means that the number of institutional investors in China's stockmarkets could increase considerably over the coming years. The QFIl scheme is also an integral part of the Chinese Government's efforts to encourage institutional investment in that country's stockmarkets, though the scheme has been slow on the uptake. Its primary objective is to allow foreign companies to trade in the A-based share market. While the QFII scheme is expected to be successful, there has been some scepticism in the 
scheme because the money is tied up for a period of two to three years, the governance of stockmarkets, particularly in the area of transparency, needs to be improved, and there is a shortage of quality stocks.

In the light of its role as a primary means of encouraging institutional investment in China, there is general consensus that the National Social Security Fund could become one of the largest institutional investors in that country, and, indeed, in the Asian region. Some commentators, such as DiBiasio (2002b:28) have noted that it could become a very significant and influential institutional investor in Asia, with the exception of those investors found in Japan.

In the second half of 2002, the Council of the NSSF invited tenders to manage part of its funds. The tender was open to any company that met the qualifying conditions (See Box 19.1) as laid down in the Temporary Methods for the Investment and Management of the National Social Security Fund, which were issued jointly by the Ministries of Finance and Labour and Social Security. ${ }^{3}$

The tender process clearly favoured domestic Chinese funds management companies, ${ }^{4}$ and excluded the possibility of joint ventures or foreign companies being able to manage NSSF funds because none of them had a two-year track record. It is also important to bear in mind that this tender determined the first group of companies eligible to manage social security funds. It is reasonable to expect that more opportunities to manage these funds will arise in the future, and the

\section{Box 19.1 Qualifying conditions to manage funds in the NSSF}

The qualifying conditions to manage funds in the NSSF are as follows

- Be registered in China or be an investment management organisation of the kind stipulated by the State Council;

- Have a licence from the China Securities Regulatory Commission as a funds management company;

- Possess real capital of not less that RMB 50 million, and, at any time, have not less than RMB 50 million in net assets;

- Have had a representative office in China for more than two years, and possess more than two years experience in securities and investment management in China;

- Be cautious in the management of funds, have a high reputation, and possess a standard international operational structure;

- Have no evidence of illegal behaviour in the last three years;

- Possess a perfected corporate governance structure;

- Have enough competent staff specialised in funds management; and

- Possess a comprehensive and effective internal risk management system, including an independent regulation section. 
Chinese Government has indicated that this will happen (Yang 2003). In the future, it may be possible for foreign funds management companies to have the opportunity to manage NSSF assets, particularly if they exploit the opportunities created by China's recent accession to the World Trade Organization (WTO). However, this will take time. Under the accession rules, foreign funds management companies can own up to 33 per cent of a funds management company immediately, and 49 per cent of the company three years after China's accession to WTO. Moreover, foreign and joint venture funds management companies also will be able to manage pension funds. At present, there are already a number of joint venture funds management companies in China, although it is unclear whether they are currently licensed to manage funds in that country. ${ }^{5}$

The six fund management companies selected to manage part of the NSSF's assets were given formal approval to invest a portion of those funds on the stock market. Before commencing operations, they were required to sign an agreement with the NSSF.

When appointing the funds managers, the Council of the NSSF also discussed the rates of return that it hopes to achieve if the funds managers wish to keep their mandates. Those target rates of return are quite ambitious. They must be at least three percentage points higher than the rate of price inflation, and 120 per cent of the yearly interest rate for a term deposit in a bank (Yang 2003). To clarify the point, it should be noted that these target retums are by no means definite at this stage and are still the subject of much discussion by the Council of the NSSF. If those targets are being considered seriously by the Chinese Government, then it is likely to provide enough of an incentive for the funds managers. It may lead the fund managers to seek positive absolute rates of return for the monies under their control.

In total, RMB 28 billion ( $\mathrm{A} \$ 5.6$ billion) was made available to the fund management companies. Nanfang Fund Management, Boshi Fund Management and Huaxia Fund Management companies each received RMB 6-7 billion (A\$1.2-1.4 billion), while Changsheng Fund Management, Penghua Fund Management and Jiashi Fund Management companies received RMB 3 billion ( $A \$ 600$ million) each to invest. The funds available to each of these funds management companies can only be invested in stocks and bonds (Yang 2003; Xiao 2003). The total amount of funds to be invested will enter the stockmarkets gradually. This is being done, in part, to avoid any perception by individual investors that there is a flood of money going into China's stockmarkets, which could cause prices to rise. It should be recognised that there 
are no guarantees that the entry of the NSSF will boost the value of the stockmarkets. In a recent article, the China Daily (2003) commented that the entry of the fund could not sustain buying momentum on 13 June 2003, and that it is expected to provide a boost in the medium to long term only. Approximately half of the RMB 28 billion ( $\mathrm{A} \$ 5.6$ billion) will enter the stock market within a short space of time and it is understood that RMB 4 billion ( $A \$ 800$ million) will be invested within three months from June 2003 (Xin 2003).

Given the importance of the NSSF for the Chinese Government, there were also a number of restrictions placed upon the funds managers with regard to the investment of NSSF assets. In particular, investment funds managed by funds management companies in China's stockmarkets should not rise above 80 per cent, and investment in bonds must not exceed 20 per cent. The total administrative costs of the six funds management companies must not exceed 10 per cent of the value of assets in the National Social Security Fund, and funds managers cannot hold more than five per cent of a listed company's shares. Such restrictions on the investment of NSSF assets indicate the sensitive nature of the fund, and the Chinese Government's desire for its assets to be invested in a safe and reliable way, while still maintaining and increasing its value. In recent times, there has been discussion within the Chinese Government surrounding the possibility of a Qualified Domestic Institutional Investor (QDII) scheme, which is likely to be an even more sensitive issue than the QFIl scheme, as investments under the QDII scheme are capital outflows. There may be scope for the NSSF to participate in the QDII scheme, but it remains unclear whether it would be allowed to do so.

\section{CONCLUSION}

The chapter has provided a description of the management, funding and operation of China's National Social Security Fund, and the most recent developments in that regard. Its establishment indicates that the Chinese Government is looking to the future, and that it is making an effort to solve China's future pension problems. The most recent developments regarding the NSSF, particularly that of allowing it to hire fund managers to invest in the stockmarket, also suggest that there is a conscious effort on the part of the Chinese Government to maintain and increase its value. In addition, the chapter has demonstrated that it is an important vehicle for the development of the funds management industry in China, and for encouraging institutional investors in that country's stockmarkets. It is also clear that the NSSF 
will assist the Chinese Government in meeting its future pension liabilities. In this context, it is highly likely that the Chinese Government will proceed with great caution to ensure and maintain the integrity of its National Social Security Fund.

\section{ACKNOWLEDGMENTS}

The author wishes to acknowledge the comments of Stuart Leckie, Chairman of the Hong Kong Retirement Schemes Association, for his invaluable comments on a previous version of this chapter. In addition, the author wishes to thank Leon Trainor, Director, Capacity Building, International Branch, and Annabelle Cassells, Assistant Director, Capacity Building, International Branch, Department of Family and Community Services for their support and encouragement.

\section{NOTES}

1 Dr Ogborn, a former employee of the Australian Department of Family and Community Services, was involved in a World Bank funded social security reform project between 1999 and 2002 . His comments were sourced from information obtained by comments he provided on a previous paper by the author.

2 Principal Insurance, a US based company, is training NSSF staff in funds management, and is keen to keep that relationship going after its contract expires, though it is unclear what form that relationship would take (DiBiasio 2002a). Northern Trust Investor Services is providing assistance to the NSSF with regard to its risk management systems, including asset allocation, investment management monitoring, performance reporting (Northern Trust Corporation, 2003). Caisse des Dépots et Placements du Quebec is assisting the NSSF in relation to investment management (DiBiasio 2002b:28).

3 My translation

4 At that time, only ten domestic Chinese companies were in a position to manage NSSF funds. Those companies were: Nanfang Fund Management, Guotai Fund Management, Penghua Fund Management, Fuguo Fund Management, Jiashi Fund Management, Hua'an Fund Management, Boshi Fund Management, Changsheng Fund Management, Dacheng Fund Management and Huaxia Fund Management.

5 At least three foreign funds management companies have set up joint venture funds management companies with Chinese companies, and could, potentially, manage NSSF funds in the future. Those companies are Allianz AG from Germany with Guotai Jun'an Securities, SG Asset Management from France with the Huabao Trust and Investment Company, and ING with China Merchant Securities. 
Joint venture funds management companies in China requires two licences. The first licence gives permission to set up a joint venture funds management company, while the second allows the company to launch funds. As such, approval to set up a joint venture has been given, but it remains unclear whether they have been granted the other license necessary to manage funds (Information obtained from the author's discussion with Stuart Leckie, Chairman of the Hong Kong Retirement Schemes Association).

Of relevance to Australia, Colonial First State, the funds management arm of the Commonwealth Bank of Australia, is awaiting the China Securities Regulatory Commission's approval to participate in a joint venture funds management company with Hantong Securities from Shenzhen (DiBiasio 2003b; Korporaal 2003).

\section{REFERENCES}

China Daily, 2003. 'Entry of welfare fund fails to push up stocks', China Daily, 13 June 2003. Available online at http://www1.chinadaily.com.cn/news/cb/2003-0613/119094.html [Accessed 16 June 2003].

China Fortune Securities, 2003. 'Quanguo Shehui Baozhang Jijin Niandu Baogao (2002 Niandu)', China Fortune Securities Website, 2 June 2003. Available online at http://www.cfs.com.cn/zfzq/content/html/20030602/content002004008 _. 1000652276.html [Accessed 16 July 2003].

China Labour Net, 2003. 'Shebao Jijin Qunian Shouyilu 2.75\%', China Labour Net Website, 2 June 2003. Available online at http://www.labournet.com.cn/ldnews/ fileview.asp?fileno=7201 [Accessed: 3 June 2003].

DiBiasio, J., 2002a. 'China Fund hires principal for training', Finance Asia Magazine, 12 April 2002. Available online http://www.financeasia.com/articles/E7B276544207-11D6-81DE0090277E174B.cfm [Accessed 16 July 2003].

- 2002b. 'With a little help from my friends', Pensions Asia, Summer 2002:28.

_- 2003a. 'China Fund outsources first mandates', Finance Asia Magazine , 7 January 2003. Available online at http://www.financeasia.com/articles/F7FE57011F9C-11D7-81F20090277E174B.cfm [Accessed 12 March 2003].

_ 2003b. 'First State applies for China Fund JV', Finance Asia Magazine, 3 June 2003. Available online at http://www.financeasia.com/articles/C6A0BBC68E83-11D7-81FA0090277E174B.cfm [Accessed 3 June 2003].

Korporaal, G., 2003. 'CBA sets China raising', The Courier Mail, 16 June 2003. Available online at http://www.thecouriermail.news.com.au/common/story_page/ $0,5936,6602176 \% 5 E 462,00$. html [Accessed 16 June 2003]. 
Leckie, S., 2001. Pension Funds in China, Presentation at International Pensions Seminar, Brighton, 6-7 June. Available online at http:/www.actuaries.org/ members/en/events/seminars/Brighton/presentations/leckie.pdf [Accessed 16 July 2003].

- 2002. Retirement Benefits in Hong Kong and China, Presentation to Pensions Policy Initiative for Policy Dialogue Workshop, Sydney, 4 March 2002. Available: online at http:/www.pensions-policy.org/papers/sydney/China.pdf [Accessed: 16 July 2003].

Northern Trust Investor Services, 2003. 'Northern Trust News: Northern Trust to Assist China's National Social Security Fund', Northern Trust Investor Services Website, Chicago. Available online at http://www.ntrs.com/aboutus/news/ 030109.html [Accessed: 16 July 2003].

Liaoning Provincial Government, 2002. Social Security Fund Plans For Larger Amount To Enter Stock Market, Liaoning Provincial Government Website, Liaoning. Available online at http://www.In.gov.cn/zwxx/tx02072306.htm [Accessed 25 July 2002].

Sun, Min, 2003. 'QFlls in no rush to enter markel', China Daily, Hong Kong Edition, 15 January 2003.

Tang, Yuankai, 2003. 'Social security fund debuts on market', Beijing Review, 46 (27):30-31

Xiao, K., 2003. 'Shebao Jijin Touzi Gupiao Fudong Wusun 3.63 Yi Yuan: Shei Lai Mai Dan', Xinhua, 3 June 2003. Available online at http://news.xinhuanet.com/fortune/ 2003-06/03/content_901105.htm [Accessed 5 June 2003].

Xin, Zhiming, 2003. 'Pension fund needs time in market', China Daily, 19-20 July.

$X u, X$. and Chen, Y., 2002. 'Zhongguo Shebao Jijin Yunzuo Moshi Jiben Queli' [Operational model of China's social security fund basically determined], Xinhua News Agency Website, 9 May 2002. Available online at http://news.xinhuanet.com/ newscenter/2002-05/09/content_386622.htm [Accessed 10 May 2001].

Yang, D., 2003. 'Shebao Jijin Shouci Rushi Zong'e Yue 140 Yi: Na Xie Pinzhong Cheng Shou Xuan', Xinhua News Agency Website, 3 June 2003. Available online at http://news.xinhuanet.com/fortune/2003-06/03/content_900603.htm [Accessed 4 June 2003]. 